\title{
BEBERAPA KOMPETENSI DAN SIKAP KEPROFESIAN DOSEN JURUSAN PENDIDIKAN BIOLOGI FTK UIN RADEN INTAN LAMPUNG
}

\author{
Agus Jatmiko $^{1}$ \\ ${ }^{1}$ UIN Raden Intan Lampung, Jl. Letkol H. Endro Suratmin Sukarame Bandar Lampung \\ e-mail: agusjatmiko@ radenintan.ac.id
}

Diterima : 03 November 2018. Disetujui: 20 November 2018. Dipublikasikan: 29 Desember 2018

\begin{abstract}
Abstrak
Tujuan penelitian ini adalah untuk mengetahui kemampuan dosen dalam menyusun strategi instruksional, menyusun alat evaluasi, menyusun bahan ajar, dan sikap dosen terhadap keprofesian. Jenis penelitian ini menggunakan metode deskriptif-kualitatif. Sasaran penelitian adalah Dosen Tidak Tetap yang memberikan perkuliahan pada Jurusan Pendidikan Biologi FTK UIN Raden Intan Lampung. Hasil penelitian: 1) kemampuan dosen dalam mengembangkan pembelajaran melalui strategi pembelajaran belum terperinci secara jelas penggunaan metode, media, dan waktu yang digunakan; 2) kemampuan dosen dalam mengembangkan pembelajaran melalui kemampuan dalam menyusun alat evaluasi, muatan soal masih berorientasi pada materi belum banyak mengacu pada indikator pencapaian; 3) kemampuan dosen dalam mengembangkan pembelajaran melalui kemampuan menyusun bahan ajar secara keseluruhan masih menggunakan buku teks; 4) kemampuan dosen dalam mengembangkan pembelajaran melalui sikap terhadap profesi dosen secara keseluruhan sudah dapat menunjukkan sikap profesi kedosenan.
\end{abstract}

Kata kunci: Pembelajaran, Kompetensi Pedagogik, Sikap Keprofesian

\begin{abstract}
The purpose of this study was to determine the ability of lecturers in preparing instructional strategies, compiling evaluation tools, compiling teaching materials, and lecturers' attitudes toward professionalism. This type of research uses descriptivequalitative methods. The target of the study was the Non-Permanent Lecturers who gave lectures to the Department of Biology Education, FTK Radin Intan Lampung. The results of the study: 1) the ability of lecturers in developing learning through learning strategies has not been clearly explained the use of methods, media, and time used; 2) the ability of lecturers in developing learning through ability in compiling evaluation tools, the content of questions still oriented to the material has not been much referring to indicators of achievement; 3) the ability of lecturers in developing learning through the ability to compile teaching materials as a whole still using textbooks; 4) the ability of the lecturer to develop learning through attitudes towards the lecturer profession as a whole has been able to show the attitude of the professional lecturer.
\end{abstract}

Keywords: Learning, Pedagogic Competence, Professionalism 


\section{PENDAHULUAN}

Pendidikan merupakan suatu kebutuhan bagi umat manusia dan mempunyai peranan penting dalam rangka meningkatkan kualitas sumber daya manusia. Searah dengan usaha menggalakkan pembangunan di segala bidang, maka peningkatan mutu pendidikan yang merupakan salah satu dari tujuan pembangunan tersebut perlu mendapat perhatian besar.

Untuk mencapai tujuan pembangunan nasional tersebut, pemerintah telah mengeluarkan kebijaksanaan-kebijaksanaan yang mengatur, membina, dan mengembangkan usaha-usaha di bidang pendidikan. Salah satunya adalah UndangUndang Republik Indonesia Nomor 14 Tahun 2005 tentang Guru dan Dosen. Dijelaskan di dalam Undang-undang tersebut bahwa untuk menjamin perluasan dan pemerataan akses, peningkatan mutu dan relevansi, serta tata pemerintahan yang baik dan akuntabilitas pendidikan yang mampu menghadapi tantangan sesuai dengan tuntutan perubahan kehidupan lokal, nasional, dan global perlu dilakukan pemberdayaan dan peningkatan mutu dosen secara terencana, terarah, dan berkesinambungan. Karena dosen adalah pendidik profesional dan ilmuwan dengan tugas utama mentransformasikan, mengembangkan, dan menyebarluaskan ilmu pengetahuan, teknologi, dan seni melalui pendidikan, penelitian, dan pengabdian kepada masyarakat. ${ }^{1}$ Dengan demikian dosen yang mengajar di lingkungan satuan pendidikan tinggi mempunyai fungsi, peran, dan kedudukan yang sangat strategis dalam mencapai tujuan pembangunan nasional utamanya dalam bidang pendidikan.

Satuan pendidikan tinggi merupakan salah satu sarana dalam komponen sistem pendidikan nasional mempunyai visi dan misi untuk bertanggung jawab dalam mencerdaskan kehidupan bangsa. Oleh karena itu salah satunya dalam rangka meningkatkan kualitas pembelajaran di kelas adalah dosen sebagai tenaga pengajar. Dosen dalam proses pembelajaran dituntut untuk lebih aktif merencanakan, memilih dan membimbing semua kegiatan yang dilakukan mahasiswa agar selanjutnya dapat memberikan umpan balik yang bermanfaat bagi mahasiswanya. Sesuai dengan kompetensinya, maka ada empat kompetensi yang harus dikuasi dan dikembangkan oleh dosen, yaitu kompetensi pedagogik, kompetensi sosial, kompetensi personal, dan kompetensi profesional.

\footnotetext{
${ }^{1}$ Undang-Undang Republik Indonesia Nomor 14 Tahun 2005 tentang Guru dan Dosen, 2005. h.2.
} 
Tugas dan peranan dosen sebagai pengajar profesional sesungguhnya sangat kompleks, tidak terbatas pada saat berlangsungnya interaksi edukatif di dalam kelas, yang biasa disebut dengan proses pembelajaran, dosen juga bertugas sebagai administrator, evaluator, konselor dan seterusnya dengan mengerahkan semua kompetensi-kompetensinya atau kemampuan yang dimilikinya.

Sebenarnya salah satu tugas seorang pengajar yang pokok adalah bagaimana dapat membangkitkan dan memotivasi seoptimal mungkin agar motivasi instrinsik yang merupakan penggerak dari dalam diri dapat terbangun dalam mengembangkan potensi yang ada. Oleh karena itu setip dosen diharapkan untuk pandai-pandai mengarahkan kegiatan pembelajarannya agar tercapai keberhasilan belajar sebagaimana yang telah ditetapkan dalam sasaran tujuan pembelajaran. Sebagai konsekuensinya, tugas dan tanggung jawab dosen menjadi lebih kompleks dan menjadi lebih berat. Di sisi lain posisi dosen kadang dihadapkan pada berbagai masalah dalam kehidupannya, gaji yang pas-pasan misalnya, sehingga memaksa dosen untuk bekerja sambilan dalam memenuhi kebutuhan hidupnya. Selanjutnya, sebagian besar dosen setiap harinya harus berpindah dari satu kampus ke kampus lain dengan tujuan untuk mendapatkan tambahan pendapatan. Alhasil dosen kehabisan waktu untuk mempersiapkan diri dalam mengajar dan tidak sempat lagi mengembangkan potensi yang ada pada dirinya. Dosen yang demikian ini sangat kecil kesempatannya dalam mengembangkan kemampuan mengajar dan mengikuti perkembangan ilmu pengetahuan dan teknologi yang semakin pesat, belum lagi harus ditambah dengan berhadapan jumlah dan karakter mahasiswa peserta didiknya yang lebih dari ukuran normal.

James B. Brow sebagaimana yang dikutip Sardiman mengemukakan bahwa tugas dan peranan pengajar antara lain menguasai dan mengembangkan materi, merencanakan dan mempersiapkan pembelajaran, mengontrol dan mengevaluasi kegiatan peserta didik. ${ }^{2}$ Dalam proses pembelajaran di kelas dosenlah yang memimpin dan bertanggung jawab penuh atas kepemimpinan yang dilakukan itu. Ia tidak melakukan instruksi-instruksi dan tidak berdiri sendiri di bawah instruksi lain kecuali dirinya sendiri.

\footnotetext{
2 Arif. S.Sadiman, Media Pendidikan: Pengertian dan Pemanfaatannya (Jakarta: PT. Raja Grafindo, 2000), h.142.
} 
Berdasarkan pendapat tersebut dapat dipahami bahwa untuk dapat melaksanakan tugas mengajar dengan baik dosen sebaiknya memiliki kemampuan-kemampuan profesional yang berkaitan dengan tugas-tugas profesinya. Kemampuan-kemampuan profesional tersebut dalam bidang pendidikan selanjutnya lebih dikenal dengan istilah kompetensi profesional.

Kompetensi profesional tersebut merupakan profil kemampuan dasar yang harus dimiliki dosen. Kompetensi tersebut dikembangkan berdasarkan pada analisis tugastugas yang harus dilakukan dosen. Oleh karena itu kompetensi profesional tersebut secara operasional akan mencerminkan fungsi dan peranan dosen dalam melaksanakan proses pembelajaran. Dosen dalam tugasnya sebagai pendidik dan pengajar berupaya membimbing dan mengarahkan, memberikan petunjuk, keteladanan, dan kecakapan mengenai pengetahuan, keterampilan dan sikap terhadap mahasiswa.

Dosen dalam melaksanakan tugasnya harus bisa memahami isi jiwa, sifat mental, motivasi dan kebutuhan setiap mahasiswanya agar dia bisa memberikan arahan, bimbingan sebaik-baiknya dan seefektif mungkin yang sesuai dengan sifat-sifat individu. Selain itu masih ada beberapa kompetensi-kompetensi profesional yang harus dimiliki dosen agar dalam melaksanakan tugas pembelajaran di kelas dosen dapat berperan dengan lebih efektif, yaitu kompetensi pedagogik, kompetensi sosial, kompetensi personal, dan kompetensi profesional. Kompetensi pedagogik yaitu kemamampuan dosen yang berkaitan dengan melaksanakan pembelajaran, kompetensi sosial yaitu berkaitan dengan berhubungan dengan orang lain, kompetensi personal yaitu kemampuan yang berhubungan dengan sikap kepribadiannya, dan kompetensi profesional yaitu berkaitan dengan keahlian ilmu yang diakuasai.

Kegiatan pembelajaran sering dijumpai permasalahan yang terdapat pada beberapa set bahan pembelajaran yang harus disampaikan oleh dosen kepada para mahasiswa. Beberapa permasalahan yang terkadaang dalam pengembangan bahan pembelajaran antara lain: Pertama, bahan ajar tidak disesuaikan dengan karakteristik mahasiswa. Hal ini dapat terjadi karena penyusunan bahan ajar biasanya dibuat secara umum dengan kondisi dan keadaan mahasiswa di berbagai tempat dengan segala perbedaan karakteristik dan kemampuannya kurang mendapat pertimbangan dalam penyusunan. Kedua, alat evaluasi yang digunakan dalam bahan pembelajaran yang harus dikerjakan oleh mahasiswa terkadang disusun berdasar materi tidak berdasar pada 
indikator atau tujuan yang ingin dicapai, sehingga hasil pembelajaran terkadang cenderung kurang memuaskan baik bagi dosen maupun bagi mahasiswa sebagai pebelajar. Ketiga, materi pelajaran yang ada sekarang ini sedikit sekali yang mengaitkan anatra beberapa materi atau pada mata pelajaran lain dalam suatu bahasan. Hal ini bertolak belakang dengan prinsip-prinsip penyusunan silabus dan rancangan pembelajaran yang baik. Menurut Sakri, bahwa bahan pembelajaran yang baik haruslah dapat mengaitkan antara materi dengan materi ataupun mengaitkan antara pelajaran satu dengan pelajaran lain. ${ }^{3}$ Hal ini bertujuan untuk membangkitkan motivasi mahasiswa untuk belajar. Keempat, strategi pembelajaran yang dipilih pengajar saat ini kurang bisa mengaitkan antara pelajaran yang telah dikuasai oleh mahasiswa dengan bahan-bahan yang akan dipelajari (advance organizer).

Selanjutnya, dengan memahami beberapa kenyataan tersebut para dosen sangat diharapkan dalam pembelajaran agar dapat mengembangkan suatu set bahan ajar sehingga memungkinkan para mahasiswa untuk belajar secara mandiri dengan dilandasi adanya motivasi belajar setelah mempelajari bahan ajar yang disusun dosen tersebut.

Hal ini perlu dikaji lebih mendalam oleh karena adanya permasalahan yang berhubungan dengan pengembangan bahan instruksional tersebut yang memiliki peranan penting dalam proses pembelajaran. Di samping bahan instruksional yang harus dikembangkan sehingga memungkinkan mahasiswa belajar dengan penuh kesadaran dan motivasi belajar tinggi, maka dosen sebaiknya membekali dirinya dengan kemampuan dalam menyusun bahan pembelajaran, alat evaluasi dan menyusun strategi pembelajaran. Kemampuan pedagogik adalah kemampuan dosen dalam menyusun alat evaluasi yaitu kemampuan dosen dalam menyusun suatu alat ukur berupa tes yang dapat mengukur secara tepat kemampuan mahasiswa setelah menerima materi pelajaran. Kenyataan yang terjadi di lapangan menunjukkan bahwa tidak sedikit tes yang dibuat oleh dosen tidak mampu mengukur dengan tepat kemampuan-kemampuan yang telah dimiliki oleh mahasiswanya. Jika tes yang dibuat ini bertujuan untuk mendiagnosis kesulitan-kesulitan belajar, tentu saja kesalahan dalam membuat alat ukur (tes) akan berakibat perlakuan dosen dalam menangani kesulitan belajar tesebut, juga akan keliru sehingga tujuan pembelajaran yang direncanakan tidak akan tercapai.

\footnotetext{
${ }^{3}$ Adjat Sakri, Cara Menulis Bahan Ajar (Bandung: Institut Teknokogi Bandung, 1999), h.14.
} 
Satu hal yang sebaiknya tidak boleh dikesampingkan oleh dosen yang melaksanakan tugas pembelajaran adalah kemampuan dalam menyusun strategi pembelajaran. Strategi pembelajaran diperlukan dosen terutama untuk menentukan urutan-urutan kegiatan pembelajaran yang dilaksanakan dalam proses pembelajaran, sehingga diperoleh suatu rangkaian kegiatan pembelajaran yang efektif dan efisien dalam mencapai tujuan pembelajaran yang telah ditetapkan. Permasalahan yang berkembang sekarang ini adalah banyaknya pengajar yang melaksanakan tugas mengajarnya tanpa persiapan yang cukup, mengajar hanya asal mengajar, bahkan sedikit sekali yang membekali kegiatan pembelajarannya dengan media ataupun alat peraga yang dibutuhkan untuk membantu peserta didik dalam belajar. Untuk mencapai keberhasilan kompetensi tersebut didukung adanya keahlian yang dikuasai dengan sikap keprofesiannya. Disinyalir masih ada beberapa dosen yang mengampu mata kuliah kurang sesuai dengan bidang keahliannya oleh karena dilakukan dosen hanya untuk memenuhi tuntutan kewajiban mengajar saja.

\section{METODE PENELITIAN}

Penelitian ini dilakukan di Universitas Islam Negeri Raden Intan Lampung, selajutnya subjek penelitian difokuskan pada Dosen Tidak Tetap/Dosen Luar Biasa yang mengajar pada prodi/jurusan Pendidikan Biologi pada semester gasal tahun akademik 2018/2019 yang berjumlah 10 orang. Pelaksanaan penelitian ini secara efektif dilakukan selama dua bulan, mulai awal bulan September sampai akhir Oktober 2018.

Penelitian ini bersifat deskriptif-kualitatif dengan data-data penelitian ini adalah (1) jawaban dosen sebagai subjek penelitian yang mengajar di jurusan pendidikan bilologi pada semester gasal tahun akademik 2018/2019 Univerisitas Islam Negeri Raden Intan Lampung melalui wawancara dan obserasi. (2) Data penelitian berasal dari hasil wawancara dengan dosen sejawat berstatus dosen tetap. (3) Data penelitian dengan mengadakan catatan dan wawancara dengan ketua juruasan dan mahasiswa. (4) Data berupa dokumen-dokumen yang berkaitan dengan pengelolaan akademik seperti silabus, satuan acara perkuliahan, kumpulan soal, buku referensi, kumpulan tugas mahasiswa. Untuk mengumpulkan data penelitian ini, penulis menggunakan beberapa teknik, yakni observasi, interview dan dokumentasi. 


\section{HASIL PENELITIAN DAN PEMBAHASAN}

Strategi pembelajaran merupakan suatu perpaduan dari urutan kegiatan, cara pengorganisasian materi pelajaran dan mahasiswa, peralatan dan bahan, serta waktu yang digunakan dalam proses pembelajaran untuk mencapai tujuan pembelajaran yang telah ditentukan. Setiap pengajar memiliki cara sendiri dalam melaksanakan tugasnya sebagai pengajar. Oleh karena itu setiap pengajar mempunyai kapasitas dan kemampuan mengajar yang berbeda-beda, di samping itu haruslah disadari bahwa mengajar sebagai suatu tugas pembelajaran yang melibatkan peserta didik haruslah disesuaikan dengan keilmuan pengajar dan materi yang akan disampaikan kepada peserta didik.

Kesanggupan atau kecakapan dalam menyusun suatu strategi pembelajaran merupakan suatu kemampuan dosen dalam menyusun, mengurutkan dan memadukan urutan pembelajaran, cara pengorganisasian bahan pembelajaran dan mahasiswa, peralatan serta waktu yang digunakan selama kegiatan pembelajaran untuk mencapai tujuan pembelajaran yang telah ditetapkan dalam rangka membantu mahasiswa belajar dan mencapai tujuan pembelajaran tersebut. Kegiatan pembelajaran merupakan keadaan atau kondisi belajar yang sengaja diciptakan. Dosen sebagai pengajar harus bisa menciptakan kondisi yang sedemikian rupa guna membelajarkan mahasiswanya. Perpaduan antara dosen dengan mahasiswa ini selanjutnya dapat melahirkan interaksi edukatif dengan memanfaatkan bahan ajar maupun sumber belajar sebagai mediumnya.

Secara umum strategi pembelajaran dapat diartikan sebagai cara yang sistematis dalam mengkomunikasikan isi pelajaran kepada mahasiswa untuk mencapai tujuan pembelajaran tertentu terutama berkenaan dengan usaha bagaimana (the how) menyampaikan isi pelajaran tersebut.4 Dengan demikian strategi pembelajaran selanjutnya dapat diartikan sebagai pola-pola umum kegiatan dosen dengan mahasiswa dalam perwujudan kegiatan pembelajaran untuk mencapai tujuan yang telah digariskan.

Secara teoritis rancangan pembelajaranan yang disajikan oleh pengajar belum terperinci atau disajikan dalam bentuk Rencana Pembelajaranan Semester (RPS) secara utuh. Sehingga secara umum belum jelas kegiatan-kegiatan apa saja yang akan dilakukan oleh pengajar setiap materi atau tema yang akan disampaikan, masih menjadi satu bentuk yang sama dalam satu kegiatan kegiatan. Secara teori bahan persiapan mengajar bagi seorang pengajar sebelum melaksanakan pembelajaran minimal ada

\footnotetext{
${ }^{4}$ Rusman, Model-model Pembelajaran: Mengembangkan Profesionalisme Guru (Jakarta: PT. Rajagarafindo Persada, 2011), h. 132.
} 
empat komponen (1) harus ada rumusan tujuan yang hendak disampaikan; (2) adanya materi yang mau disampaikan; (3) menyusun strategi yang akan digunakan untuk mengajar; (4) memuat alat evaluasi untuk mengukur seberapa tingkat pencapaian materi tersebut. Tidak ada keseragaman atau format dari jurusan sehingga dalam menyusun RPS setiap pengajar berbeda-beda. Meskipun demikian bukan berarti salah, namun dapat dibenarkan asalkan minimal harus ada empat komponen tersebut di atas dalam setiap kali menyusun RPS.

Subjek penelitian yang dalam hal ini adalah pengajar belum semua dapat memahami makna strategi pembelajaran dengan baik dan secara benar. Selanjutnya, pemahaman tentang strategi pembelajaran masih disamakan artinya dengan model maupun pendekatan pembelajaran. Secara sederhana strategi pembelajaran diartikan sebagai bentuk pembelajaran di kelas. Bagaimana cara mengorganisir materi pelajaran dan peserta didik belum dapat efektif dalam kegiatan pembelajaran. Peralatan dan bahan pembelajaran yang digunakan pengajar dan mahasiswa masih minim sekali. Kurang mengorganisir bahan atau sumber-sumber belajar yang ada di sekitar kelas yang memang dapat diajadikan sebagai sumber belajar.

Pengajar kurang memperhatikan komponen yang mesti harus ada dalam setiap kegiatan pembelajaran. Adanya urutan pembelajaran, metode, media dan waktu yang digunakan dalam pembelajaran sudah biasa digunakan dalam pembelajaran, namun komponen ini kurang dipahami bahwa semua ini termasuk komponen strategi pembelajaran. Pelaksanaan komponen pembelajaran ini sudah dapat dilaksanakan dengan baik. Pada urutan kegiatan pembelajaran terutama pada tahap pendahuluan, dalam RPS masih dijelaskan kegiatan pengajar dengan mengabsen dan pemberian salam kepada peserta didiknya. Tujuan yang ingin disampaikan sudah cukup jelas, namun tidak dijelaskan relevansinya dengan peserta pebelajar. Pada tahap kegiatan inti, antara uraian materi, pemeberian contoh, dan latihan kepada mahasiswa belum ketiganya dilaksanakan secara lengkap. Media apa yang digunakan kadang tidak dicantumkan atau ditulis dalam penyusunan RPS, metode apa yang akan digunakan seperti apa, berapa waktu yang akan digunakan. Meskipun tertulis kegiatan yang akan disampaikan terkadang masih kurang dalam pengelolaan waktu tersebut, sehingga penggunaan antara waktu dengan kegiatan kurang seimbang.Pemilihan kata kerja dalam merumuskan 
indikator pencapaian masih abstrak belum dirumuskan secara operasional. Hal ini apa yang akan dicapai pebelajar secara operasional belum terukur secara tepat.

Pada Rencana Pembelajaran Semester sebagian pengajar ada yang mencamtumkan dan ada pula yang sebagian tidak menulis alat evaluasinya yang sudah disusunnya sebelum mengajar. Jenis evaluasi yang tepat adalah evaluasi formatif yang bertujuan untuk menentukan apa yang harus ditingkatkan atau direvisi agar strategi yang digunakan lebih efektif dan lebih efisien. Secara ekstrim, dapat dikatakan betapapun kurang efektif atau sangat efektifnya strategi tersebut, pengajar masih harus mencari apa yang perlu dilakukan untuk meningkatkan efektifitasnya sehingga kualitasnya lebih baik datpadasebelumnya. Hanya dengan cara itulah pengajar dapat merasa yakin bahwa sistem pembelajaran yang dikembangkan akan lebih efektif dan efisien. Sebaiknya alat evaluasi harus tetap ada dalam RPS. Hal ini alat evaluasi dimungkinkan harus tetap ada untuk memudahkan pengajar untuk mendapat umpan balik berupa keterangan hasil belajar mahasiswa selama mengikuti perkuliahan alat evaluasi harus dirancang sedemikian rupa, mencerminkan materi tang disampaikan dengan melihat tingkat kesukaran tes yang dibuatnya. Alat evaluasi yang sudah disusunnya oleh pengajar di dalam RPS masih terdapat pengajar yang kurang memperhatikan indikator-indikator ketercapaian tujuan yang diharapkan. Rumusan butir soal sebagai alat evaluasi banyak ditulis yang dibuatnya berdasarkan materi bukan pada indikator tujuan yang hendak dicapai. Sehingga kemungkinan ada tujuan pembelajaran yang belum bisa tercapai oleh karena rumusan butir tersebut belum bisa menggambarkan indikator tujuan yang mau dicapai dari materi tersebut. Alat evaluasi belum lengkap karena setiap butir soal belum disertai kunci jawabannya. Seharusnya penyusunan soal dalam rancangan pelaksanaan pembelajaran harus disertakan kunci jawabannya. Hal ini untuk memudahkan pengajar untuk melakukan koreksi terhadap jawaban pebelajar yang secara subyektif pemberian skor sesuai dengan hasil jawabannya. Kemudahan selanjutnya dapat digunakan oleh pengajar pengganti sewaktu-waktu apabila pengajar aslinya sempat berhalangan hadir. Dalam menyusun alat evaluasi pembelajaran pada RPS belum dijelaskan skor-skor penilaian. Hal ini disebutkan agar untuk memudahkan pengajar untuk melakukan koreksi terhadap jawaban pebelajar yang secara subyektif pemberian skor sesuai dengan hasil 
jawabannya. Kemudahan lain, selanjutnya dapat digunakan oleh pengajar pengganti apabila sewaktu-waktu pengajar aslinya sempat berhalangan hadir.

Mengembangkan bahan ajar yang baik didasarkan atas strategi pembelajaran Pada umumnya bentuk kegiatan pembelajaran ada tiga macam. Pertama, Pengajar sebagai fasilitator dan pebelajar belajar mandiri. Kedua, Pengajar sebagai satu-satunya sumber tunggal dan pebelajar belajar darinya. Dan ketiga, Pengajar sebagai penyaji bahan belajar yang dipilihnya atau yang sudah dikembangkannya. Hasil penelitian menunjukkan bahwa tidak seluruhnya pengajar menggunakan bahan ajar yang digunakannya tersebut hasil/karya sendiri pengajar dengan mengembangkan bahan ajar yang sudah ada, melainkan masih banyak menggunakan bahan ajar yang wujudnya buku cetak yang siap pakai dan sudah ada di pasaran, artinya bahan ajar yang digunakan tidak perlu dikembangkan lagi sesuai dengan bentuk kegiatan pembelajaran. Kadang masih dijumpai bahan ajar pengajar yang sudah dikembangkan tidak sesuai dengan bentuk kegiatan pembelajaran. Hal ini kurang memudahkan pebelajar untuk mempelajarinya bahan ajar yang sudah dikembangkan oleh pengajar tersebut. Masih dijumpai dalam bahan ajar tersebut kata-kata dengan menggunakan bahasa yang resmi, sehingga menyulitkan pebelajar untuk memahami isi materi yang ada pada bahan ajar. Hal ini tidak sesuai dengan makna buku ajar yang seharusnya berbeda sama sekali dengan buku paket atau buku cetak.

Secara keseluruhan pengajar menguasai bahan ajar yang dimilikinya. Setiap pengajar memiliki keilmuan masing-masing dan dapat disampaikan dengan baik ketika pembelajaran berlangsung. Selanjutnya dapat diketahui penjelasan pengajar yangcukup jelas kepada pebelajar dan tidak membuat pebelajar banyak bertanya dalam arti pebelajar tertib dan memahaminya materi yang disampaikan oleh pengajar. Hampir secara keseluruhan pengajar dapat memenej kelas dengan baik. Hal ini dapat dilihat adanya suasana kelas yang tenang dan nyaman tidak ada sediktpun pebelajar yang membuat suasana gaduh. Metode mengajar yang digunakan dengan apa yang sudah ditulis pada rencana pembelajaran semester kurang sesuai. Hal ini disebabkan pemahaman pengajar belum baikmasih memahaminya antara mose, strategi, metode pembelajaran masih beranggapan sama artinya. Pengajar yang mengajar di kelas sebagian dapat memanfaatkan sumber-sumber belajar yang ada disekitar kelas dengan baik. Ada sebagian bisa menggunakan baik namun ada pula yang kurang bahkan tidak 
bisa meanfaatkan sumber belajar dengan baik. Penguasaan terhadap landasan kependidikan umumnya sudah baik sesuai dan sesuai keilmuan yang pengajar miliki. Sikap kependidikan yang dijiwainya sudah nampak ketika pembelajaran berlangsung. Hal ini diperlukan agar dosen dapat menentukan sikap atau tindakan yang tepat. Untuk itu diperlukan pembekalan landasan-landasan kependidikan yang memadai alhasil pengajar dapat berhasil dalam menjalankan tugas mengajar. Kesempatan yang baik bagi pengajar untuk sering mengikuti berbagai pelatihan atau sejenisnya seperti workshop.

\section{SIMPULAN DAN SARAN}

Simpulan dalam kajian yang telah dilakukan: pertama, kemampuan dosen dalam mengembangkan pembelajaran melalui strategi pembelajaran sudah dilakukan melalui tahapan atau urutan kegiatan pembelajaran secara jelas, namun tidak disertai penggunaan metode, media, dan waktu yang digunakan setiap tahapannya. Strategi pembelajaran yang disusun diuraikan secara rinci mengenai tahap-tahapan pembelajaran kurang disertai metode yang digunakan maupun media dan waktu kegiatan. Kedua, Kemampuan dosen dalam mengembangkan pembelajaran melalui kemampuan dalam menyusun alat evaluasi, muatan soal lebih banyak berorientasi pada materi daripada mengacu pada indikator pencapaian. Penyusunan alat evaluasi banyak merujuk pada materi pelajaran, kurang mengembangkan alat evaluasinya berdasarkan indikatorindikator pencapaian tujuan. Ketiga, Kemampuan dosen dalam mengembangkan pembelajaran melalui kemampuan menyusun bahan ajar secara keseluruhan masih banyak yang menggunakan buku teks. Sehimgga bahan ajar yang dikembangkan kurang sesuai dengan bentuk kegiatan pembelajaran yang digunakan. Kelima Kemampuan dosen dalam mengembangkan pembelajaran melalui sikap terhadap profesi dosen secara keseluruhan dapat menunjukkan sikap terhadap profesinya. Setiap kegiatan pembelajaran sudah menunjukan sikap keprofesionalitasnya baik kemampuan dalam mengelola pembelajaran maupun kemampuan keilmuannya.

Adapun saran yang dapat direkomendasikan dalam penelitian ini adalah perlu adanya pelatihan pembuatan RPS, media dan alat evaluasi bagi dosen-dosen biologi guna meningkatkan mutu pembelajaran.

\section{DAFTAR PUSTAKA}

Arends, Richard I. 1997. Classroom Instruction and Management. Mc.Graw-Hill Companies, Inc. USA. 
Arikunto, Suharsimi. 2001. Dasar-dasar Evaluasi Pendidikan. Jakarta: Bumi Aksara.

Arikunto, Suharsimi. 2006. Menejemen Pengajaran secara Manusiawi. Jakarta: PT. Rineka Cipta.

Bogdan, Robert C \& Biklen Sarl Knopp. 1982. Qualitative Research for Education an Introduction to Theory ang Methods, Boston : Allyn and Bacon, Inc,.

Ciborowski, Jean. 1998. Texbokks, and Students Who Can't Read Them. Cambridge: Brooklines books.

Dick, Walter \& Carey, Lou. 1997. The Systemic Design of Instruction. Illinois: Scott, Foresmanand Company.

Hardini, Isriani \& Puspitasari, Dewi. 2012. Strategi Pembelajaran Terpadu. Yogyakarta: Familia (Group Relasi Inti Media).

Hasibuan dan Moejiono. 2003. Proses Belajar Mengajar. Bandung: CV. Remaja Rosda Karya.

Lewis R, Aiken. 1997. Psychological Testing and Assesmenta Viacom. New York: Company Nedham Height.

Mar'at, 2002. Sikap Manusia Perubahan serta Pengukurannya. Yogyakarta: Pustaka Pelajar.

Miles, Matthew dan Huberman, A. Michael. 1992. Analisis Data Kualitatif: Buku Sumber Tentang Metode-Metode Baru. Jakarta: UI Press.

Moleong, Lexi J. 2014. Metode Penelitian Kualitatif. Bandung: Remaja Rosdakarya.

Mudhoffir, 2000. Teknologi Instruksional. Bandung: CV. Remaja Rosda Karya.

Nawawi, Hadari. 2012. Metode Penelitian Bidang Sosial. Yogyakarta: Gadjah Mada University Press.

Norman E, Gronlund. 1985. Measurement ang Evaluatin in Teaching. New York: Mac millan Company.

Pressley, Michael. 1995. Cognitive Strategy Instruction that Arealy Improves Children's Academic Performance. Cambridge: Brooklines bool.

Purwadarminta, W.J.S. 1997. Kamus Umum Bahasa Indonesia. Jakarta: Balai Pustaka.

Rusman. 2011. Model-model Pembelajaran: Mengembangkan Profesionalisme Guru. Jakarta: PT. Rajagarafindo Persada.

Sadiman, Arif S. 2000. Media Pendidikan: Pengertian dan Pemanfaatannya. Jakarta: PT. Raja Grafindo.

Sakri, Adjat. 1999. Cara Menulis Bahan Ajar. Bandung: Institut Teknokogi Bandung.

Soetjipto dan Kosasi, Raflis. 2005. Profesi Keguruan. Jakarta: PT. Rineka Cipta. 
Sugiyono. 2007. Metode Penelitian Pendidikan. Bandung: Alfabeta.

Suparman, M. Atwi. 2001. Desain Instruksional. Jakarta: PAU-PPAI Universitas Terbuka.

Suryosubroto, Sumadi B. 2001. Proses Belajar Mengajar di Sekolah. Jakarta: PT Rineka Cipta.

Sutrisno Hadi. 2004. Metode Research. Yogyakarta: Andi Offset.

Undang-Undang Republik Indonesia Nomor 14 Tahun 2005. Tentang Guru dan Dosen. 